\title{
PENGARUH RELIGIUSITAS TERHADAP PELANGGARAN ETIKA PADA SISWA KELAS XI MIA 4 DAN XI IIS 2 SMA NEGERI 14 KOTA BANDUNG
}

\author{
Erni Purnamasari, * \\ Makhmud Syafe'i, Kokom Siti Komariah \\ Program Studi Ilmu Pendidikan Agama Islam, \\ Fakultas Pendidikan Ilmu Pengetahuan Sosial, Universitas Pendidikan Indonesia \\ *E-mail:erni.purnamasari@gmail.com
}

\begin{abstract}
ABSTRAK
Kehidupan remaja kita saat ini sering dihadapkan pada berbagai masalah yang sangat kompleks sehingga mengakibatkan timbulnya efek negatif dari masyarakat yang akhir-akhir ini semakin merisaukan. Efek negatif tersebut misalnya, semakin maraknya penyimpangan-penyimpangan di berbagai norma kehidupan, baik itu agama maupun sosial. Hal ini tentunya perlu mendapatkan perhatian dari kita semua. Salah satu masalah tersebut adalah semakin menurunnya tatakrama dalam kehidupan sosial dan etika moral remaja dalam praktik kehidupannya, baik itu di rumah, di sekolah dan di mana pun ia tinggal. Sampai saat ini, masalah remaja masih tetap menjadi salah satu fokus perhatian bagi bangsa kita. Untuk itu, dibutuhkan pemahaman mengenai ajaran agama guna mengurangi permasalahan tersebut. Oleh karena itu, tujuan dari penelitian ini yaitu untuk mengetahui pengaruh religiusitas terhadap pelanggaran etika pada siswa. Penelitian dilaksanakan di SMA Negeri 14 Bandung. Penelitian menggunakan pendekatan kuantitatif dengan metode deskriptif. Data penelitian diambil menggunakan angket religiusitas dan pelanggaran etika. Teknik analisis data yang digunakan adalah analisis regresi sederhana. Hasil penelitian menunjukkan bahwa ada hubungan antara religiusitas terhadap pelanggaran etika pada siswa kelas XI MIA 4 dan XI IIS 2 SMA Negeri 14 Bandung. Hasil uji regresi diperoleh R-Square 0,598 yang berarti religiusitas berpengaruh terhadap pelanggaran etika siswa sebesar 59,8 \% dan sisanya 40,2 \% dipengaruhi oleh faktor lain yang belum ditemukan dalam penelitian ini. kesimpulannya dalam penelitian ini ada pengaruh religiusitas terhadap pelanggaran etika pada siswa kelas XI MIA 4 dan XI IIS 2 SMA Negeri 14 Kota Bandung.
\end{abstract}

Kata Kunci: Religiusitas, Pelanggaran Etika, Tatakrama, Norma, Etika 


\section{PENDAHULUAN}

Masa remaja adalah masa peralihan, yang ditempuh oleh seseorang dari kanak-kanak menuju dewasa. Atau dapat dikatakan bahwa masa remaja adalah perpanjangan masa kanak-kanak sebelum mencapai masa dewasa. Berapa banyaknya orang tua yang mengeluh, bahkan bersusah hati, karena anak-anaknya yang telah remaja itu menjadi keras kepala, sukar diatur, mudah tersinggung, sering melawan dan sebagainya. Bahkan ada orang tua yang benar-benar panik memikirkan kelakuan anak-anaknya yang telah remaja, seperti sering bertengkar, membuat kelakuankelakuan yang melanggar aturan atau nilai-nilai moral dan norma-norma agama (Daradjat, 2010, hlm. 81).

Kehidupan remaja kita saat ini sering dihadapkan pada berbagai masalah yang amat kompleks yang tentunya sangat perlu mendapat perhatian kita semua. Salah satu masalah tersebut adalah semakin menurunnya tatakrama kehidupan sosial dan etika moral remaja dalam praktik kehidupan, baik di rumah, sekolah, maupun lingkungansekitarnya, yang mengakibatkan timbulnya sejumlah efek negatif di masyarakat yang akhirakhir ini semakin merisaukan. Efek tersebut misalnya, semakin maraknya penyimpangan di berbagai norma kehidupan, baik agama maupun sosial, yang terwujud dalam bentuk-bentuk perilaku antisosial seperti tawuran, pencurian, pembunuhan, penyalahgunaan narkoba, dan lain sebagainya (Syafaat dkk, 2008, hlm. 2).
Masalah remaja merupakan topik pembicaraan di berbagai negara, terutama pada tahun 1985. Tahun tersebut telah ditetapkan oleh Perserikatan Bangsa-Bangsa sebagai Tahun Pemuda Internasional. Sampai saat ini, masalah remaja masih tetap menjadi salah satu fokus perhatian bagi setiap bangsa di dunia (Syafaat dkk, 2008, hlm. 2).

Suatu kenyataan bahwa etika telah mulai redup di dalam dunia pendidikan kita. Pendidikan di sekolah telah terreduksi, menjadi penyampaian pengetahuan saja, tidak lagi mendidik karakter. Sehingga saat ini siswa lebih banyak menghafal ketimbang memperoleh pendidikan karakter yang baik. Mendidik bukan lagi sebagai suatu seni yang dilandasi dengan hati dan kasih sayang yang selalu muncul adalah wajah seram pendidik yang siap memberikan hukuman. Contohnya adalah siswa yang tidak sopan terhadap gurunya, siswa tersebut berani melawan saat guru sedang menasehati dan memberikan hukuman kepada siswa tersebut, karena telah melanggar tata tertib yang telah diberlakukan oleh pihak sekolah. Peristiwa tersebut mengindikasikan bahwa pendidikan etika itu tidak lagi menjadi landasan pendidikan akhlak dan moral yang menjadi dasar dari pembentukkan karakter.

Arifin (2012, hlm. 47) menegaskan bahwa "dalam pergaulan hidup bermasyarakat, diperlukan sistem yang mengatur bagaimana seharusnya manusia bergaul. Sistem pergaulan tersebut diperlukan untuk menjaga kepentingan masing-masing 
agar kehidupan manusia menjadi aman, tenteram, terlindungi, terjamin sesuai dengan norma yang berlaku, dan tidak bertentangan dengan hak-hak asasi manusia. Sistem pergaulan yang dibuat dan diterapkan dari dan untuk kepentingan kelompok sosial tertentu itulah yang disebut dengan etika".

Sebagai ilmu, etika diartikan sebagai refleksi kritis, metodis, dan sistematis tentang tingkah laku manusia. Etika memuat tentang apa yang harus dilakukan, apa yang tidak boleh dilakukan, apa yang baik, dan apa yang buruk. Dengan adanya etika, perilaku-perilaku yang baik diatur berdasarkan nilai-nilai moral yang berlaku dalam masyarakat. Etika sangat memengaruhi kehidupan manusia. Etika akan memengaruhi tindakan manusia karena berperan membantu manusia untukmemutuskan apa yang akan dilakukan dan apa yang harus dihindari. Segala aspek kehidupan manusia akan diwarnai oleh etika yang dimilikinya (Arifin, 2012, hlm. 49).

Dalam pengertian di atas etika ditekankan pada arti niai-nilai dan norma-norma etis yang menjadi pegangan bagi seseorang atau suatu kelompok dalam mengatur tingkah lakunya di dalam berkehidupan bermasyarakat. Di dalam kehidupan sosial bermasyarakat warga dituntut untuk mematuhi apa yang telah ditetapkan oleh masyarakatnya sebagai aturan, tata nilai, serta larangan. Semakin kompleks kehidupan masyarakat semakin banyak aturan adat, larangan yang diperuntukan bagi warganya.

Begitu pula dalam dunia pendidikan dimana siswa tidak terlepas dari peraturan-peraturan yang ditetapkan oleh pihak sekolah. Di mana adanya suatu peraturan maka apabila ada yang melanggar peraturan yang telah dibuat harus menerima konsekuensi yaitu bentuk hukuman yang telah ditetapkan pula oleh pihak sekolah. Maka dari itu siswa harus mematuhi peraturan atau tata tertib yang telah diterapkan di dalam sekolah. Apabila siswa melanggar peraturan yang dibuat oleh sekolah maka siswa tersebut harus menerima konsekuensi atau akibat dari perbuatan nya sendiri. Tetapi sebelum peraturan sekolah itu diberlakukan sebaiknya pihak sekolah harus bekerja sama dengan orang tua siswa mengenai peraturan yang akan diberlakukan dan sanksi apa yang akan siterima oleh siswa apabila melanggar tata tertib yang akan diberlakukan.

Untuk menanamkan etika yang baik sebagai makhluk sosial, individu membutuhkan orang lain untuk bertahan hidup dan melangsungkan hidupnya dengan baik. Dukungan sosial yang terdiri atas dukungan keluarga, teman sebaya, dan lingkungan sekolah akan memberikan dampak bagi kehidupan seseorang. Sebab, dengan adanya dukungan sosial, seseorang akan lebihmerasakan bahwa hidupnya bermakna dengan orang-orang yang ada di sekitarnya bahwa mereka peduli dan menyayanginya sehingga ia dapat tetap survive menjalani kehidupan.

Seperti yang diungkapkan oleh Jalaluddin (2002, hlm. 75) bahwa "tingkat religiusitas pada remaja akan berpegaruh terhadap perilakunya. Apabila remaja memiliki tingkat religiusitas yang tinggi, maka remaja 
akan menunjukkan perilaku ke arah hidup yang religius pula. Sebaliknya, remaja yang memiliki tingkat religiusitas rendah, mereka akan menunjukkan perilaku ke arah hidup yang jauh dari religius pula. Hal ini berarti remaja memiliki potensi untuk melakukan penyimpanganpenyimpangan atau kenakalankenakalan terhadap ajaran agama yang dianutnya".

Bagi anak remaja, sangat diperlukan danya pemahaman, pendalaman, serta ketaatan terhadap ajaran-ajaran agama yang dianut. Kenyataan sehari-hari menunjukkan bahwa anak-anak remaja yang melakukan kejahatan sebagian besar kurang memahami norma-norma agama, bahkan mungkin lalai menunaikan perintah-perintah agama (Syafaat dkk, 2008, hlm. 3).

Situasi dan kondisi lingkungan masyarakt kita, jika dilihat saat ini sangat rentan bagi tumbuhnya perilaku agresif dan menyimpang di kalangan remaja. Hampir setiap hari kita saksikan dalam realitas sosial, perilaku menyimpang yang dilakukan oleh remaja, seperti menurunnya tatakrama sosial dan etika moral dalm praktik kehidupan sekolah dan masyarakat yang mengarah pada akses negatif, yang pada dasarnya tidak sesuai dengan nilai-nilai agama sebagaimana terangkum dalam akhlak karimah. Kita saksikan pula, pada kenyataan sekarang ini mulai dirasakan melemahnya keteladanan guru dan orang tua di mata anak, siswa, dan remaja, sehingga cenderung mencari identifikasi pada sumber-sumber lain untuk dicontoh dan ditiru (Syafaat dkk, 2008, hlm. 4).

\begin{abstract}
Dari paparan di atas penulis dapat menyimpulkan bahwa religiusitas memiliki peranan penting dalam perilaku seseorang. Seseorang yang kurang membekali dirinya dengan arahan dan bimbingan keagamaan dalam kehidupannya, maka dengan kondisi seperti itu akan menjadi salah satu penyebab berkembangnya perilaku seseorang yang akan berdampak pada setiap perbuatannya.Melalui penelitian ini peneliti berupaya untuk mengkaji mengenai Pengaruh Religiusitas Terhadap Pelanggaran Etika.
\end{abstract}

\section{METODE}

Dalam penelitian ini, menggunakan desain korelasional. Melalui pendekatan korelasional, penelitian ini dapat memperoleh informasi mengenai taraf hubungan yang terjadi, yaitu hubungan antara variabel bebas (X), yaitu Religiusitas dengan variabel terikat (Y), yaitu pelanggaran etika.

Desain korelasi bertujuan untuk mengetahui keeratan hubungan di antara variabel-variabel yang diteliti tanpa melakukan suatu intervensi terhadap variasi variabel-variabel yang bersangkutan. Data yang diperoleh merupakan data alamiah seperti apa adanya. Kendali parsial yang dilakukan terbatas pada kontrol statistikal dalam analisisnya sehingga dimungkinkan untuk melihat hubungan di antara dua variabel (Azwar, 2012, hlm. 21).

$$
\text { Jumlah partisipan yang }
$$
direncanakan dalam penelitian ini adalah kurang lebih dari 80 orang siswa yang berstatus sekolah di SMAN 14 Bandung. Selain siswa, ada jumlah 
tiga orang guru yaitu guru PAI, wakasek kesiswaan, dan guru BK yang nantinya akan di lakukan wawancara dengan guru tersebut.

Sampel adalah bagian dari jumlah dan karakteristik yang dimiliki oleh populasi tersebut (Sugiyono, 2014, hlm. 81). Azwar (2012, hlm. 79) mengatakan bahwa "sampel adalah sebagian dari populasi. Karena ia merupakan bagian dari populasi, tentulah ia harus memiliki ciri-ciri yang dimiliki oleh populasinya".

Adapun teknik sampling yang digunakan dalam penelitian ini adalah teknik sampling purposive, menurut Sugiyono (2014, hlm. 85) "sampling purposive adalah teknik penentuan sampel dengan pertimbangan tertentu". Jadi peneliti mempertimbangkan terlebih dahulu dengan mendiskusikannya kepada guru PAI, wakasek kesiswaan, dan guru BK yang bersangkutan demi mempermudah penelitian. Sampel penelitian dalam penelitian ini adalah siswa kelas XI MIA 4 dan siswa kelas XI IIS 2 di SMAN 14 Bandung.

Instrumen penelitian biasanya digunakan untuk mengukur nilai-nilai dari variabel yang diteliti. Sugiyono (2014, hlm. 102) mengungkapkan bahwa "instrumen penelitian adalah suatu alat yang digunakan mengukur fenomena alam maupun sosial yang diamati. Secara spesifik semua fenomena ini disebut variabel penelitian. Jumlah instrumen penelitian tergantung pada jumlah variabel penelitian yang telah ditetapkan untuk diteliti”.

Variabel bebas adalah variabel yang mempengaruhi atau yang menjadi sebab perubahannya atau timbulnya variabel dependen (terikat). Pada penelitian ini terdapat satu variabel bebas yaitu religiusitas. Religiusitas didefinisikan sebagai suatu keadaan gambaran dalam diri seseorang yang mendorong mereka untuk bertingkah laku. Religiusitas dalam penelitian ini tergambar dari derajat skor skala religiusitas berdasarkan penggabungan beberapa dimensi religiusitas yang dikemukakan dalam Ancok dan Suroso dengan berpandangan terhadap dimensi religiusitas yang dikemukakan oleh Glock dan Stark. Berdasarkan hasil penggabungan beberapa dimensi tersebut, didapatkan lima dimensi yang dianggap telah mewakili religiusitas. Kelima dimensi tersebut yaitu: dimensi keyakinan, dimensi peribadatan, dimensi pengalaman, dimensi pengetahuan agama, dan dimensi penagamalan atau konsekuensi.

Variabel terikat yang menjadi penelitian ini adalah kelas XI MIA 4 dan kelas XI IIS 2. Variabel terikat adalah variabel yang dipengaruhi atau yang menjadi akibat, karena adanya variabel bebas. Dalam penelitian ini yang menjadi variabel terikatnya adalah pelanggaran etika siswa. Pelanggaran etika adalah perilaku atau tindakan yang dilakukan oleh siswasiswi kelas XI SMAN 14 Bandung yang melanggar aturan-aturan dan tata tertib sekolah yang dicatat dalam jurnal sehingga dapat merugikan dirinya sendiri. Pelanggaran etika yang akan diteliti dalam penelitian ini meliputi: terlambat masuk sekolah, membolos, tidak masuk sekolah tanpa keterangan, merokok di lingkungan sekolah, memakai seragam tidak lengkap, berkata tidak sopan kepada guru, dan tidak mengerjakan tugas. 
instrumen penelitian yang akan digunakan untuk melakukan pengukuran dengan tujuan menghasilkan data kuantitatif yang akurat dan jelas untuk dapat dengan mudah diolah. Instrumen penelitian ini adalah angket atau kuesioner. Achmadi (2009, hlm. 76) "angket atau kuesioner adalah suatu daftar yang berisikan rangkaian pertanyaan mengenai sesuatu masalah atau bidang yang akan diteliti. Untuk memperoleh data, angket disebarkan kepada responden".

Adapun jenis angket yang digunakan dalam penelitian ini adalah angket tertutup. Nasution (2009, hlm. 129) mengatakan bahwa "angket tertutup terdiri atas pertanyaan atau pernyataan dengan sejumlah jawaban tertentu sebagai pilihan. Responden mencek jawaban yang paling sesuai dengan pendiriannya".

Model skala pengukuran yang digunakan dalam penelitian ini adalah scala likert, skala likert digunakan untuk mengukur sikap, pendapat, dan persepsi seseorang atau sekelompok tentang kejadian atau gejala sosial. Dalam penelitian gejala sosial ini telah ditetapkan secara spesifik oleh peneliti, yang selanjutnya disebut sebagai variabel penelitian (Riduwan, 2012, hlm. 12).

Angket atau kuesioner ini dijadikan alat untuk memperoleh informasi tentang religiusitas siswa dan pelanggaran etika yang disebarkan kepada siswa kelas XI MIA 4 dan siswa kelas XI IIS 2 di SMAN 14 Bandung yang menjadi sampel dalam penelitian ini. Jumlah sampel keseluruhan dalam penelitian ini sebanyak 76 orang dari dua kelas.
Prosedur dalam penelitian ini yaitu:

1. Pra penelitian

Dalam tahapan ini, peneliti menentukan beberapa ruang lingkup penelitian yang akan diteliti, sebagai berikut.

Ruang Lingkup Materi. Permasalahan yang menjadi kajian pokok dalam penelitian ini adalah terdiri dari dua variabel yaitu variabel bebas/ $\mathrm{X}$ (Independen) adalah variabel yang mempengaruhi atau yang menjadi sebab perubahannya atau timbulnya variabel dependen (terikat). Pada penelitian ini terdapat satu variabel bebas yaitu religiusitas. Variabel terikat/ Y (dependen) adalah variabel yang dipengaruhi atau yang menjadi akibat, karena adanya variabel bebas. Dalam penelitian ini yang menjadi variabel terikatnya adalah pelanggaran etika siswa.

Ruang Lingkup Subjek. Subjek pada penelitian ini adalah siswa yang bersekolah di SMAN 14 Bandung kelas XI MIA 4 dan kelas XI IIS 2 yang berjumlah 76 orang dari dua kelas yang dijadikan subjek penelitian. Selain itu peneliti melakukan wawancara terlebih dahulu untuk mengumpulkan data, wawancara dilakukan kepada guru PAI, guru BK, dan wakasek kesiswaan.Ruang Lingkup Lokasi. Lokasi penelitian ini adalah di SMAN 14 bertepatan di Jalan Yudhawastu Pramuka IV kota Bandung.

Ruang Lingkup Waktu. Waktu pada pra penelitian ini dilaksanakan pada tanggal 20 Januari tahun 2015.Penyusunan Angket dan Studi 
Dokumentasi. Dalam tahapan ini peneliti membagi penyusunan angket berdasarkan variabel yang ada, yakni untuk Angket A adalah variabel $(\mathrm{X})$ yaitu religiusitas dan Angket B adalah variabel (Y) yaitu pelanggaran etika.

2. Tahap Pelaksanaan Penelitian

Pada tahap pelaksanaan penelitian ini akan dilakukan, proses pengumpulan data dan informasi, analisis data dan penarikan kesimpulan yang akan dilakukan. Adapun langkah-langkah yang ditempuh peneliti adalah menghubungi bagian wakasek kurikulum, untuk meminta konfirmasi izin penelitian.Menentukan responden yang dibutuhkan dalam penyebaran angket. Menyebarkan angket kepada responden. Melakukan wawancara kepada Guru PAI, wakasek kesiswaan dan guru BK. Melaksanakan pengumpulan data dari sumber dokumentasi sekolah yang diteliti dan studi pustaka yang sesuai dalam judul penlitian. Peneliti melakukan penyusunan data kembali dari perolehan hasil angket, wawancara, dan studi dokumen.

Dalam penelitian kuantitatif, analisis data merupakan kegiatan setelah data dari seluruh responden atau sumber data lain terkumpul. Teknik analisis data dalam penelitian kuantitatif menggunakan statistik. Statistik yang digunakan untuk analisis data dalam penelitian ini yaitu statistik deskriptif.

Metode penelitian deskriptif, yaitu menganalisis dan menyajikan fakta secara sistematik sehingga dapat lebih mudah untuk dipahami dan disimpulkan. Kesimpulan yang diberikan selalu jelas dasar faktualnya sehingga semuanya selalu dapat dikembalikan langsung pada data yang diperoleh (Azwar, 2012, hlm. 6).

Statistik deskriptif adalah statistik yang digunakan untuk menganalisis data dengan cara mendeskripsikan atau menggambarkan data yang telah terkumpul sebagaimana adanya tanpa bermaksud membuat kesimpulan yang berlaku untuk umum atau generalisasi (Sugiyono, 2014, hlm. 147).

Dengan menggunakan penelitian kuantitatif, data-data yang diperoleh berupa angka-angka sebagai alat untuk menemukan keterangan atau informasi mengenai apa yang ingin diketahui dalam penelitian ini, dan menguji hipotesis secara empiris. Kemudian hasil dari data numerikal tersebut dianalisis dengan menggunakan uji statistik atau dengan program SPSS pada komputer agar dapat menjawab dari permasalahan yang diteliti.

Metode analisis data yang selanjutnya digunakan dalam penelitian ini adalah analisis regresi. Riduwan (2011, hlm. 147) mengemukakan bahwa " regresi atau peramalan adalah suatu proses memperkirakan secara sistematis tentang apa yang paling mungkin terjadi di masa yang akan datang berdasarkan informasi masa lalu dan sekarang yang dimiliki agar kesalahannya dapat diperkecil. Jadi, regresi mengemukakan tentang keingintahuan apa yang terjadi di 
masa depan untuk memberikan kontribusi menentukan keputusan yang terbaik".

Kegunaan regresi dalam penelitian salah satunya adalah untuk meramalkan atau memprediksi variabel terikat (Y) apabila variabel bebas (X) diketahui. Regresi sederhana dapat dianalisis karena didasari oleh hubungan fungsional atau hubungan sebab akibat (kausal) variabel bebas (X) terhadap variabel terikat (Y). karena ada perbedaan yang mendasar dari analisis kolerasi dan analisis regresi (Riduwan, 2011, hlm. 148).

\section{HASIL DAN PEMBAHASAN}

Berdasarkan penelitian diperoleh hasil temuan yaitu sebagai berikut:

\section{a. Religiusitas Siswa}

Penyebaran angket/kuesioner yang dijadikan instrumen dalam pengumpulan informasi tentang religiusitas siswa disebarkan kepada siswa kelas XI MIA 4 dan XI IIS 2 yang dilakukan pada tanggal 6 April 2015. Angket terdiri atas 43 butir (item).

Berdasarkan data perolehan, maka dapat diketahui bahwa religiusitas pada siswa kelas XI MIA 4 dan XI IIS 2 di SMA Negeri 14 Bandung berada dalam kriteria tinggi sebanyak 0 siswa $(0 \%)$ berada dalam kriteria sedang sebanyak 67 siswa (88 $\%)$ berada dalam kriteria rendah sebanyak 9 siswa (12\%) dan berada dalam kriteria sangat rendah sebanyak 0 siswa $(0 \%)$. Dapat disimpulkan pada uraian di atas menunjukkan bahwa religiusitas pada siswa kelas XI MIA 4 dan XI IIS 2 di SMA Negeri 14 Bandung berada pada kriteria sedang, yaitu sebesar $88 \%$.

Setelah data religiusitas siswa diperoleh langkah selanjutnya adalah melakukan uji normalitas, uji normalitas data dilakukan untuk membuktikan apakah data yang diperoleh berdistribusi normal atau tidak. Tujuan uji normalitas adalah untuk menguji apakah dalam sebuah model regresi, variabel terikat dan variabel bebas atau keduanya mempunyai distribusi normal ataukah tidak. Model regresi yang baik adalah distribusi data normal atau mendekati normal. Uji normalitas dalam penelitian ini menggunakan teknik One-Sample Kolmogrov-Smirnov.

$$
\text { Diperoleh data nilai }
$$

Kolmogrov-Smirnov religiuitas siswa sebesar $0,166>0,05$, artinya nilai signifikasi untuk religiusitas lebih besar dari pada 0,05 maka dapat disimpulkan bahwa data tersebut berdistribusi normal.

\section{b. Pelanggaran Etika}

Penyebaran angket/kuesioner yang dijadikan instrumen dalam pengumpulan informasi tentang pelanggaran etika siswa disebarkan kepada siswa kelas XI MIA 4 dan XI IIS 2 yang dilakukan pada tanggal 6 April 2015. Angket terdiri atas 48 butir (item).

Berdasarkan kriteriadi atas, maka dapat diketahui bahwa pelanggaran etika pada siswa kelas XI MIA 4 dan XI IIS 2 di SMA Negeri 14 Bandung berada dalam 
kriteria tinggi sebanyak 44 siswa (58 $\%)$ berada dalam kriteria sedang sebanyak 32 siswa (42 \%) berada dalam kriteria rendah sebanyak 0 siswa $(0 \%)$ dan berada dalam kriteria sangat rendah sebanyak 0 siswa (0 $\%$ ). Dapat disimpulkan pada uraian di atas menunjukkan bahwa pelanggaran etika pada siswa kelas XI MIA 4 dan XI IIS 2 di SMA Negeri 14 Bandung berada pada kriteria tinggi, yaitu sebesar $58 \%$.

Setelah data pelanggaran etika siswa diperoleh langkah selanjutnya adalah melakukan uji normalitas, pengujian normalitas dilakukan untuk mengetahui apakah data berdistribusi normal atau tidak. Uji normalitas dalam penelitian ini menggunakan teknik One-Sample KolmogrovSmirnov.

\section{c. Pembahasan Religiusitas Siswa}

Dilihat berdasarkan dari hasil penelitian yang dilakukan terhadap 76 orang siswa kelas XI MIA 4 dan XI IIS 2 SMA Negeri 14 Bandung. Adapun hasil yang diperoleh untuk variabel religiusitas siswa yang meliputi; keimanan, peribadatan, pengalaman beragama, pengetahuan agama dan konsekuensi beragama.

Untuk indikator keimanan memperoleh nilai 1.471 dari 8 butir pertanyaan yang disajikan dan jika dipersentasekan sebesar $60 \%$. Untuk alternatif jawaban dari indikator religiusitas yang disajikan ada 4 alternatif. Dari 76 jumlah responden yang dijadikan sampel penelitian ini memiliki kategori keimanan yang sedang secara keseluruhan.
Untuk indikator peribadatan memperoleh nilai 2.016 dari 12 butir pertanyaan yang disajikan dan apabila dipersantasekan sebesar 55 $\%$. Untuk alternatif jawaban dari indikator religiusitas yang disajikan ada 4 alternatif. Dari 76 jumlah responden yang dijadikan sampel penelitian ini memiliki kategori peribadatan yang sedang secara keseluruhan.

Untuk indikator pengalaman beragama memperoleh nilai 588 dari 3 butir pertanyaan yang disajikan dan apabila dipersantasekan sebesar 64 $\%$. Untuk alternatif jawaban dari indikator religiusitas yang disajikan ada 4 alternatif. Dari 76 jumlah responden yang dijadikan sampel penelitian ini memiliki kategori pengalaman beragama yang sedang secara keseluruhan.

Untuk indikator pengetahuan agama memperoleh nilai 1.002 dari 6 butir pertanyaan yang disajikan dan apabila dipersantasekan sebesar 55 $\%$. Untuk alternatif jawaban dari indikator religiusitas yang disajikan ada 4 alternatif. Dari 76 jumlah responden yang dijadikan sampel penelitian ini memiliki kategori pengetahuan agama yang sedang secara keseluruhan.

Untuk indikator konsekuensi beragama memperoleh nilai 2.640 dari 14 butir pertanyaan yang disajikan dan apabila dipersantasekan sebesar $62 \%$. Untuk alternatif jawaban dari indikator religiusitas yang disajikan ada 4 alternatif. Dari 76 jumlah responden yang dijadikan sampel penelitian ini memiliki kategori konsekuensi beragama yang sedang secara keseluruhan. 


\section{d. Pembahasan Pelanggaran Etika}

Pelanggaran etika adalah semua perbuatan yang melanggar atau melawan hukum dan menyalahi norma-norma atau aturan-aturan yang berlaku dalam masyarakat yang dilakukan oleh siswa sehingga dapat merugikan dirinya sendiri maupun orang lain yang ada di sekitarnya. Berdasarkan hasil penelitian, secara umum pelanggaran etika pada siswa kelas XI MIA 4 dan XI IIS 2 SMA Negeri 14 Bandung berada pada kriteria tinggi dan sedang.

Data yang diperoleh mengungkapkan hasil yang lebih rinci mengenai pelanggaran etika. Pelanggaran etika dalam penelitian ini memiliki 7 indikator yaitu terlambat masuk sekolah, membolos, tidak masuk sekolah tanpa keterangan, merokok, memakai seragam tidak lengkap, berkata tidak sopan dan tidak mengerjakan tugas.

Indikator yang pertama yaitu terlambat masuk sekolah pada siswa berada pada kriteria tinggi yaitu sebesar $79 \%$. Hal ini menujukkan bahwa mayoritas siswa kelas XI MIA 4 dan XI IIS 2 SMA Negeri 14 Bandung ini datang terlambat ke sekolah.

Indikator yang kedua yaitu membolos pada siswa berada pada kriteria tinggi yaitu sebesar $78 \%$. Hal ini Hal ini menujukkan bahwa mayoritas siswa kelas XI MIA 4 dan XI IIS 2 SMA Negeri 14 Bandung ini mereka membolos saat mata pelajaran berlangsung.

Indikator yang ketiga yaitu tidak masuk sekolah tanpa memberikan surat keterangan. Pada indikator ini mayoritas siswa Hal ini menujukkan bahwa mayoritas siswa kelas XI MIA 4 dan XI IIS 2 SMA Negeri 14 Bandung ini tidak memperhatikan dan tidak memperdulikan surat ijin ketika mereka tidak bisa masuk. Pada indikator ini memiliki kriteria yang tinggi sebesar $77 \%$.

Indikator yang keempat yaitu merokok di lingkungan sekolah. Merokok di lingkungan sekolah pada siswa berada pada kriteria yang sedang yaitu dengan persentase $54 \%$.

Indikator yang kelima yaitu memakai seragam tidak lengkap. Berbeda dengan indikator yang lainnya, memakai seragam tidak lengkap pada siswa berada pada kriteria yang tinggi. Hal ini dibuktikan dengan persentase sebesar $82 \%$. Hal ini menunjukkan bahwa mayoritas siswa cenderung menyepelekan aturan-aturan yang sudah ditetapkan oleh pihak sekolah.

Indikator yang keenam yaitu berkata tidak sopan. Berdasarkan hasil analisis penelitian bahwa indikator ini berada pada kriteria yang sedang yaitu sebesar $70 \%$. Hal ini menunjukkan minoritas siswa dapat menjaga ucapannya.

Indikator yang ketujuh tidak mengerjakan tugas. Berdasarkan hasil analisis deskripsi penelitian bahwa indikaor ini memiliki kriteria yang tinggi yaitu sebesar $78 \%$. Hal ini menunjukkan bahwa sebagian besar siswa tidak mengerjakan tugas yang diberikan oleh guru. 


\section{e. Pembahasan Pengaruh Religiusitas terhadap Pelanggaran Etika}

Berdasarkan dari data hasil uji korelasi penelitian diperoleh hasil yang menunjukkan da hubungan negatif antara religiusitas dengan pelanggaran etika pada siswa kelas XI MIA 4 dan XI IIS 2 SMA Negeri 14 Bandung. Hasil dari korelasi antara religiusitas dengan pelanggaran etika menunjukkan bahwa hubungan antara religiusitas dengan pelanggaran etika menunjukkan hubungan negatif yang signifikan. Artinya, jika religiusitas tinggi maka pelanggaran etika rendah sebaliknya jika religiusitas rendah maka pelanggaran etika tinggi.

Hubungan yang signifikan tersebut didukung dengan adanya nilai regresi antara variabel religiusitas dan pelanggaran etika $(\mathrm{R}$ Square) sebesar 59,8\% pelanggaran etika pada siswa kelas XI MIA 4 dan XI IIS 2 SMA Negeri 14 Bandung dipengaruhi oleh religiusitas. Sisanya 40,2 \% dipengaruhi oleh faktor lain. Berdasarkan koefisien korelasi dan nilai signifikasi yang telah dijelaskan di atas dapat disimpulkan bahwa adanya hubungan antara religiusitas dengan pelanggaran etika pada siswa memiliki korelasi negatif.

Hasil tersebut sejalan dengan teori yang mendukung dalam penelitian ini bahwa "Sikap keagamaan merupakan suatu keadaan yang ada dalam diri seseorang yang mendorongnya untuk bertingkah laku sesuai dengan kadar ketaatannya terhadap agama. Sikap keagamaan tersebut oleh adanya konsistensi antara kepercayaan terhadap agama sebagai unsur kognitif, perasaan terhadap agama sebagai unsur efektif dan perilaku terhadap agama sebagai unsur konatif. Jadi, sikap keagamaan merupakan integrasi secara kompleks antara pengetahuan agama, perasaan agama serta tindak kegamaan dalam diri seseorang. Hal ini menunjukkan bahwa sikap keagamaan menyangkut atau berhubungan erat dengan gejala kejiwaan" (Rakhmat, 2012, hlm. 257).

Sejalan dengan teori di atas, Syafaat dkk, (2008, hlm. 3) bagi anak remaja, sangat diperlukan adanya pemahaman, pendalaman, serta ketaatan terhadap ajaran-ajaran agama yang dianut. Kenyataan sehari-hari menunjukkan bahwa anak-anak remaja yang melakukan kejahatan sebagian besar kurang memahami norma-norma agama, bahkan mungkin lalai menunaikan perintah-perintah agama.

Begitu pula penelitian yang dilakukan oleh Adelina Hasyim melalui Tesis Magisternya di IKIP Bandung/UPI (1988) tentang tindakan pelanggaran etis menemukan, bahwa sekolah-sekolah yang kaya dengan nuansa dan pembelajaran agama berpengaruh positif terhadap perilaku moral para siswanya. Dengan mengambil sampel 5 Madrasah Aliyah (MA) dan 5 SMA di Sumatera Selatan Adelina Hasyim menyimpulkan bahwa, responden siswa SMA lebih banyak melakukan pelanggaran etis ketimbang responden siswa Madrasah Aliyah (Rahmat M, 2012, hlm. 5).

Berdasarkan data hasil penelitian di atas, penulis 
menyimpulkan bahwa tingkat religius seseorang dapat mempengaruhi tingkah laku yang ada pada diri seseorang. Tingkah laku merupakan wujud dari kepribadian seseorang, apakah perbuatannya itu termasuk tingkah laku yang baik atau buruk. Ataukah tingkah laku yang sesuai dengan etika Islām. Siswa harus memiliki tingkah laku yang baik sesuai dengan ajaran Islām. Dengan demikian, peran orang tua, guru dan lingkungan sekitar harus bisa meminimalisir tingkah laku yang tidak sesuai dengan aturan.

\section{KESIMPULAN}

Religiusitas pada siswa kelas XI MIA 4 dan XI IIS 2 SMA Negeri 14 Bandung secara umum cukup baik (88 \%) berada pada kriteria "sedang". Adapun sebagian kecil responden berada pada kriteria "rendah" (12\%).

Pelanggaran etika pada siswa kelas XI MIA 4 dan XI IIS 2 SMA Negeri 14 Bandung berada pada kriteria tinggi sebesar 44 siswa (58\%). Adapula beberapa siswa yang masuk pada kriteria sedang sebesar 32 siswa (42\%). Hal ini menujukkan bahwa sebagian besar siswa tidak mematuhi peraturan yang ditetapkan oleh pihak sekolah. Kriteria tinggi terdapat pada indikator memakai seragam tidak lengkap dan terlambat masuk sekolah.

Terdapat pengaruh religiusitas terhadap pelanggaran etika pada siswa kelas XI MIA 4 dan XI IIS 2 SMA Negeri 14 Bandung. Hubungan yang signifikan ini sebesar 59,8\% sisanya 40,2 \% dipengaruhi oleh faktor-faktor lain yang belum terungkap dalam penelitian ini.

\section{REFERENSI}

Achmadi, C. N. (2009). Metodologi Penelitian. Jakarta: Bumi Aksara.

Arifin, B. d. (2012). Etika dan Profesi Kependidikan. Jogjakarta: Ar-Ruzz Media.

Azwar, S. (2012). Metode Penelitian. Yogyakarta: Pustaka Pelajar.

Barnawi, \& Arifin. (2012). Etika \& Profesi Kependidikan. Yogyakarta: Ar-Ruzz Media. Daradjat, Z. (2010). Ilmu Jiwa Agama. Jakarta: Bulan Bintang.

Nasution. (2009). Metode Research (Penelitian Ilmiah). Jakarta: Bumi Aksara.

Rahmat, J. (2012). Metode Penelitian Komunikasi. Bandung: PT Remaja Rosdakarya Offset.

Rahmat, M. (2012). Filsafat Akhlak. Bandung: Value Press.

Rakhmat, J. (2012). Psikologi Agama Edisi Revisi. Jakarta: PT Grafindo Persada.

Riduwan. (2011). Belajar Mudah Penelitian. Bandung: CV. ALFABETA.

Riduwan. (2012). Skala Pengukuran VariabelVariabel Penelitian. Bandung: CV. ALFABETA.

Sugiyono. (2014). Metode Penelitian Kuantitatif, Kualitatif dan $R \& D$. Bandung: Alfabeta.

Syafaat dkk. (2008). Peranan Pendidikan Agama Islam Dalam Mencegah Kenakalan Remaja. Jakarta: PT RajaGrafindo Persada. 